\title{
BIBLICAL PERCEPTIONS ABOUT DIVERSITY AND IDENTITY IN A WORLD OF MIGRATION
}

\author{
Ph.D. Chréstos G. KARAGIANNIS,
}

Assistant Professor of the Old Testament,

National and Kapodistrian University of Athens

Theology School, Department of Theology,

GREECE,

E-mail: ckaragiannis@theol.uoa.gr

\begin{abstract}
Diversity means the fact of many different types of things or people being included in something; a range of different things or people. Identity is associated with something individual. Migration is the movement of people into another country or region that are not native. It is a phenomenon that has occurred since ancient times and is caused by something painful that affects the inhabitant of an area. This is usually a plague, climatic phenomena, hunger, thirst or war. As the world becomes increasingly urbanized, societies tend to become more and more diverse culturally, politically, religiously and economically, and pluralism is becoming the order of the day in all these spheres. In a migrating word diversity comes close to identity and then the discussion about the limits of its one begins. The Bible provides us with a good number of narratives as to the way in which diversity is caused, how the identity of biblical Israel has been shaped, and characteristic examples of biblical forms that have led to migration. A typical example of all is Jesus Christ Himself, who in his teaching has demonstrated how modern man ought to stand on issues such as diversity, identity and migration.
\end{abstract}

Keywords: Diversity; Identity; Migration; Israel; Patriarchs; Bible; Old Testament; New Testament;

\section{INTRODUCTION}

The Bible is the book which contains the revelation of God and is constituted by Old and New Testament. Both Testaments were formatted in the land of Palestine/Israel containing ideas and traditions that derive from the Ancient Near East, the Canaanite region and the Greco-Roman civilization. It is from these cultural backgrounds that we shall discuss diversity, identity and migration. To say it simply, we cannot read the Bible except to come into dialogue or confrontation with the cultural assumptions recorded therein. Thus, reading the Bible is a meeting of cultures.

\section{DIVERSITY, IDENTITY AND MIGRATION IN THE OLD TESTAMENT}

According to the Cambridge English Dictionary diversity means the fact of many different types of things or people being included in something; a range of different things or people. On the other hand the basic meaning of the English word "identity" is: 1. The collective aspect of the set of characteristics by which a thing is definitively recognizable or known. 2. The set of behavioral or personal characteristics by which an individual is 
recognizable as a member of a group. 3. The name or nature of a person or thing. As in most other dictionary entries, the focus is on the characteristics of a person, an individual. ${ }^{1}$ Although the definition above mentions that it also has something to do with group membership, identity is usually understood as a personal aspect. The term "identity" is used differently in anthropology, sociology and social psychology. ${ }^{2}$

In the recent years the two words «diversity» and «identity» seem to be strongly associated with the idea of migration. Migration is the movement of people into another country or region that are not native. It is a phenomenon that has occurred since ancient times and is caused by something painful that affects the inhabitant of an area. This is usually a plague, climatic phenomena, hunger, thirst or war. As the world becomes increasingly urbanized, societies tend to become more and more diverse culturally, politically, religiously and economically, and pluralism is becoming the order of the day in all these spheres. In a migrating word diversity comes close to identity and then the discussion about the limits of its one begins.

\section{a. Diversity}

At Babel, the famous tower, Yahweh punishes humanity for its attempt to reach him or to bring him down from heaven on earth (gen. 11:8-9). From that tower, whose builders tried to reach the heavens, the descendants of Noah's sons spread out to their distant territories with their languages $(10: 5,20,31-32)$. Thus begins diversity in the world. ${ }^{3}$ The Tower of Babel is not a story about dissent and brokenness but an explanation for the multiplicity of languages and traditions existing in the world. ${ }^{4}$

Consequently, such an explanation offers the possibility to see cultural diversity as a positive feature of human societies. The few scholars ${ }^{5}$ who do not take the traditional punishment approach have noted various features of the text which, when brought together, provide strong arguments in support of this interpretation. Similarly, the story of Noah in Genesis 6-9 is a veritable statement in favor of diversity and growth. Noah is tasked with ensuring the survival of each and every form of life God has created and, in the concluding covenant, humans are again commanded to multiply and fill the face of the earth. This connects well with the table of nations in Genesis 10, which bridges the story of the Flood with the story of Babel and whose purpose seems evident - to present the diversification of human language and culture as the status quo.

\section{b. Identity}

The Old Testament's idea about shaping group identity is evident in the distinction which was made between God's chosen covenant people, Israel, and all other people groups in the Ancient Near East. The New Testament's emphasis is on shaping an identity that is characterized by its faith in Jesus as the Risen Messiah. Identity, and the way it is

\footnotetext{
${ }^{1}$ Reader's Digest Great Illustrated Dictionary, Ilson et al. 1984:836.

${ }^{2}$ R. Byron, "Identity", Barnard, A. \& Spencer, J. (eds), Encyclopedia of Social and Cultural Anthropology, London: Routledge, 1996, p. 292. T. M. Luhrmann, "Identity in anthropology", Smelser, N. J. \& Baltes, P. B. (eds), International Encyclopedia of the Social \& Behavioral Sciences, Volume 21, Amsterdam: Elsevier 2001, p. 7154 .

${ }^{3}$ J. G. Wenham, Genesis 1-15, [Word Biblical Commentary 1], Dallas, TX: Word Books 1987, pp. 232-246.

${ }^{4} \mathrm{~N}$. Blough, "From the Tower of Babel to the Peace of Jesus Christ: Christological, Ecclesiological and Missiological Foundations for Peacemaking", Mennonite Quarterly Review 76 (2002), 7-33.

5 W. J. Aageson, "City-Building and the Benefits of Babel", Christian Century 106 (1989) 517-518. W. Brueggemann, Genesis. A Commentary for Teaching and Preachingi, Interpretation, Atlanta, GA: John Knox Press 1982, pp. 97-104. T. Hiebert, "The Tower of Babel and the Origin of the World's Cultures", Journal of Biblical Literature 126 (2007) 29-58.
} 
represented or constructed in the Bible, is complex and one should rather speak of an array of identities that are in constant interaction with one another. Viewing Israel's identity from a religious perspective is the most traditional way of studying this ancient society.

The crossing of the Red Sea curved a new identity for Israel. In Egypt Israel's identity was that of a slave. ${ }^{6}$ The crossing of the $\mathrm{Sea}^{7}$ and the wandering in the Sinai desert gave the chance to Israel to learn God and create its identity. ${ }^{8}$ Liverani $^{9}$ makes clear that the "very existence of a political entity 'Israel' before the monarchic period must remain a matter of doubt." "Israelite religion during the period of the monarchy $\left(10^{\text {th }}\right.$ ce. B.C.) was predominantly a nationalistic and territorial [particularistic] faith while the destruction of the temple (586 B.C.) ensured the rise of a more universalistic faith". ${ }^{10}$ Inclusive or exclusive religious identity in the Old Testament is usually linked to the identity of Yahweh. The religious conception about Yahweh had a dual meaning: 1. According to the tribal Jacob tradition Yahweh is genealogically related to other gods and 2. according to the Deuteronomistic and priestly traditions Yahweh has no genealogy. ${ }^{11}$ This promoted Yahweh as the only God and resulted in Yahwistic monotheism. This Post-exilic Yahwehmonotheism shaped the whole of the Old Testament. ${ }^{12}$

\section{c. Migration}

The value of humanity, begins with the theological premise that all human beings are made in the image and likeness of God (Gen 1.26). ${ }^{13}$ Humanity is to "fill the earth" (Gen $1: 28$; cf. 9:7). Indeed, the directive at the very beginning of the biblical grand narrative presupposes movement. and, truly, migration has characterized the history. In Genesis migration also springs from divine judgment: The first persons are sent out of the garden, east of Eden, for their rebellion (3:22-24); Cain must wander for murdering his brother Abel (4:12-16). But before sending him away, God puts a mark of protection on Cain - so that no one will kill him. The criminal migrant was protected so he would not be harmed in his

${ }^{6}$ F. O. Olojede, The Exodus and Identity Formation in View of the Origin and Migration Narratives of the Yoruba, University of Stellenbosch 2008, p. 110.

${ }^{7}$ C. Houtman, Exodus Vol. 2. Historical Commentaryon the Old Testament, Kampen: Kok 1996, p. 232.

${ }^{8}$ R. B. Dillard \& T. Longman, An Introduction to the Old Testament, Grand Rapids: Zondervan 1994, p. 66.

${ }^{9}$ M. Liverani, "Nationality and political identity", Freedman, D. N., (ed). Anchor Bible Dictionary, Volume 4. New York: Doubleday 1992, p. 1034.

${ }^{10}$ G. M. Brett, "Nationalism and the Hebrew Bible", Rogerson, J W, Davies, M \& Carroll, D. R. (ed.), The Bible in ethics: The second Sheffield colloquium, Sheffield: Sheffield Academic Press 1995, p. 151.

${ }^{11}$ A. De Pury, "Erwägungen zu einem vorexilischen Stämmejahwismus. Hosea 12 und die auseinandersetzung um die Identität Israels und seines Gottes", Dietrich, W \& Klopfenstein, M. A. (eds.), Ein Gott allein? JHWHVerehrung und biblischer Monotheismus im Kontext der israelitischen und altorientalischen Religionsgeschichte. Göttingen: Vandenhoeck \& Ruprecht 1994, p. 414.

${ }^{12}$ This idea of Israel constructing her identity by constructing the identity of her deity, Yahweh. This leaves room for the idea that, although Yahweh became the national God in the 8th-century, the Jacob legend was still the formative myth of the Yahweh cult and had to be opposed by the prophets, who erased the idea that Yahweh's identity had anything to do with a relationship (genealogical) to other deities. (A. De Pury, "Erwägungen", p. 432). Albertz, sees the twofold conception of Israel as, on the one hand, a genealogical conception of a twelve-tribe nation, and on the other hand, a theological conception as the people of God, as two sides of the same coin. He sees the theological and the socio-political elements in both. Ultimately the religious uniqueness of Israel's faith and identity is that Israel defined itself as a people that is constituted in the first place by its personal relation to its God Yahweh This self-conception of Israel does not, however, follow a type of "natural" concept of nation, but opts for Yahweh's loving self-binding to his people, and Israel's thankful binding to their God as that which defines the people of God. (R. Albertz, "Volk Gottes und die Völker nach dem Alten Testament”, Reformierte Kirchen Zeitung 6 (1996) 279-285.

13 D. G. Groody, "Building a Civilization of Love: Catholic Social Teaching and Immigration Reform," Sojourners, March 2010, 24. 
wanderings. The generations continued on the earth, and the biblical story picked up with Abraham. It is there that God spoke to Abraham and said, "Go from your country and your kindred and your father's house to the land that I will show you" (Genesis 12:1). Furthermore the bless to Abraham in Gen. 12:3 is very clear: All the nations will be blessed because of you. As Konstantinou suggests "posterior theological analysis of the incident proves that Israel's faith to the revelation of God does not come in conflict with the admittance of different religious perceptions about others". ${ }^{14}$ Abraham, Sarai, and Lot became migrants going into and out of Canaan, they journeyed toward the Negreb and because of famine went down to Egypt to reside there as an alien - a stranger (Genesis 12:10). They came out of Egypt and eventually separated, with Lot settling near Sodom on the plain of the Jordan and Abraham settling by the oaks of Mamre in Hebron (Genesis 13).

In Genesis 15, God told Abraham of his role in the migration story. It is stated: "Know this for certain, that your offspring shall be aliens in a land that is not theirs, and shall be slaves there, and they shall be oppressed for four hundred years" (Genesis 15:13). God continued by telling Abraham that his offspring would come back to the land of Abraham in four generations. In Genesis 18:1-8, God appears to Abraham as three strangers near the oaks at Mamre. He offers the three men - the strangers - hospitality. He refers to them as "my Lord" and offers them the best of what he has. This is the first biblical description of ideal inclusive hospitality - of giving the very best to strangers - who in this case turned out to be God.

The biblical concept of hospitality is based in offering hospitality to the stranger, the sojourner, the alien, the migrant and the foreigner. It can be verified in Deuteronomy 6, which speaks of being brought into a new land by the Lord. This and many other passages in Deuteronomy, which will be included later, stress the importance of being one with the strangers in the land. The importance of this concept of hospitality is seen in the story of Sodom and Gomorrah. Lot welcomed the angels, but the townspeople did not. Their lack of hospitality to the stranger brought about their destruction.

The biblical migration story continued including all the patriarchs. A famine is causing Isaac to settle in the land of Gerar as an alien (Genesis 26:2). Jacob was forced to flee because of his brother's violence. He settled "where his father had lived as an alien, the land of Canaan" (Genesis 37:1). Slavery and trafficking are seen when Joseph was sold into slavery by his brothers, and was transported to Egypt. Joseph overcame the circumstances that forced him into slavery and following God's instructions to care for strangers by offering hospitality he welcomed the strangers - his brothers who left Canaan and migrated to Goshen, where there was food and Joseph welcomed them (Genesis 37-47).

The story of the Exodus - is the story of the movement of the people of God away from slavery and injustice to freedom and new life. It is perhaps the world's greatest and best-known migration story. Exodus narrative begins with the Hebrews being oppressed by their taskmasters. Their leader Moses was saved from death as he was placed in a basket in the river. In today's language he would be referred to as an "Unaccompanied Alien Child." Moses witnessed the oppressive treatment of the Hebrews by the Egyptians, he killed an Egyptian, and became a criminal alien, who fled for his life to a strange land. He became a refuge. Then he returned to Egypt, and facilitated the Exodus. Finally the people of Israel permitted to leave as most refugees leave with God leading them. According to Exod. 14:7 God migrated with them seeking to protect them and providing manna and water and all they

${ }^{14}$ M. Konstantinou, Religious Diversity and Biblical Revelation, Interpretative approach based on the Old Testament, https://www.academia.edu/1624342/Religious_Diversity_and_Biblical_Revelation. 
needed to survive. After the entrance to the Promised Land God is the one who takes care about the orphan and the widow, and who loves the strangers, providing them food and clothing (Deut. 10:17-19). One of the commands is: You shall also love the stranger, for you were strangers in the land of Egypt." Deut. $23: 7,{ }^{15} 26^{16}$ and $27: 19^{17}$ echo the same perception.

The biblical Law lists the sojourner with other at-risk groups: The poor, the widows, and the orphans. ${ }^{18}$ Widows and orphans would find it hard to survive in those farming communities, because the family would have lost the mature male needed to do the hard physical work of tilling the land. The poor and the sojourner did not have the necessary resources to provide for their families, and the sojourner had the additional obstacles. Accordingly, there were laws that provided several means to acquire food (Lev 19:9-10, Deut. 24:19-22, Deut. 14:28-29; 26:12-13). ${ }^{19}$ At the same time, there were laws directed specifically at those immigrants desiring to become part of Israelite society. ${ }^{20}$ The moral demands and practical actions that arise from the enduring biblical imperative is to love the neighbour, and to look after the alien (Lev. 19:34). ${ }^{21}$

The story of uprooted people continues throughout the Hebrew Bible as people of Israel occupy the Promised Land and are eventually sent into Exile and later return. In the time of Babylonian Captivity everyone was on the move and most went into Exile at some time. This includes the prophets, the priests, and the people. None remained except the poorest people of the land." The migration story is key to understanding biblical ancestry.

The great escape of the Jews with Persian imperial support- according to the Esther narrative - shows that this literature wanted to point out that there was no religious discrimination. The prophetic writing of Jonah represents a universalist perspective on the place of Gentiles in God's plan in which the point of view is reflected that non-Israelites may have access to the God of Israel. ${ }^{22}$ The book of Ruth, ${ }^{23}$ speaks about a Moabite female who was an immigrant and Boaz married her, giving her status in the land. ${ }^{24}$ She nevertheless opted to settle in Judah and to adopt the Yahwistic religion. By the marriage with Boaz she gave birth to a son who became an ancestor of King David and Jesus. ${ }^{25}$

\footnotetext{
15 "You shall not detest an Edomite, for he is your brother; you shall not detest an Egyptian, because you were an alien in his land."

${ }^{16}$ The verse shows the relationship between each and every person's and the care for the alien.

17 "Cursed is he who distorts the justice due an alien, orphan, and widow".

18 D. L. Baker, Tight Fists or Open Hands? Wealth and Poverty in Old Testament Law, Grand Rapids, MI: Eerdmans 2009, pp. 176-189.

${ }^{19}$ They were to be allowed to harvest the edges of the fields and a special triennial tithe of produce was to be collected to provide them sustenance.

${ }^{20}$ R. Carroll, Christians at the Border: Immigration, the Church, and the Bible. Grand Rapids, MI: Baker Academic 2008, pp. 91-112.

${ }^{21}$ W. R. Oee Neill and W. C. Spohn, "Rights of Passage: The Ethics of Immigration and Refugee Policy," Theological Studies 59 (1998) 84-106.

${ }^{22}$ L. Grabbe, A History of the Jews and Judaism in the Second Temple Period. Volume 1. Yehud: A History of the Persian Province of Judah, London: T\&T Clark, 2004, p. 312. On the other hand Neh. 13:23-25 reflect a strong exclusivist or particularistic understanding of the Jewish identity. The strong polemic in these texts is particularly directed against the neighbouring nations again.

${ }^{23}$ W. H. P. Lau, Identity and Ethics in the Book of Ruth: A Social Identity Approach, Berlin, Germany: De Gruyter 2011.

${ }^{24}$ L. Chan, "The Hebrew Bible and the Discourse on Migration: A Reflection on the Virtue of Hospitality in the Book of Ruth, Asian Horizons 8/4 (2014) 665-679.

${ }^{25}$ D. Bergant, "Ruth: The Migrant Who Saved the People," G. Campese and P. Ciallella (eds.), Migration, Religious Experience, and Globalization, Staten Island, NY: Center for Migration Studies 2003, pp. 49-61.
} 


\section{DIVERSITY, IDENTITY AND MIGRATION IN THE NEW TESTAMENT}

A crucial point is that the New Testament begins with a migration story. According to the Gospel the Christ Child was born in a cave - a stable. Because of Herod's threat Jesus, Mary and Joseph flee to Egypt, as strangers (Matthew 2:13-15).

Christ as a former stranger ${ }^{26}$ taught how to treat a stranger in Matthew 25:35-41. “...For I was hungry and you gave me food, I was thirsty and you gave me something to drink, I was a stranger and you welcomed me, I was naked and you gave me clothing, I was sick and you took care of me, I was in prison and you visited me.... Truly I tell you, just as you did it to one of the least of these who are members of my family, you did it to me." In Matthew 25:40, he clearly states that all, including people who might be seen as the "least of these," are members of his family.

When Jesus is asked by the young man, "Who is my neighbor?", Jesus answers through the parable of the Good Samaritan in Luke 10:33. Hebrews 13:1-3 urges, "Let mutual love continue. Do not neglect to show hospitality to strangers, for by doing that some have entertained angels without knowing it. Remember those who are in prison, as though you were in prison with them, those who are being tortured, as though you yourselves were being tortured." Christ comes to us in the form of the stranger, and to be one with the prisoners, the persecuted, the undocumented, the refugee, the migrant, the immigrant, the stranger. Paul reinforces this teaching in Romans 12:13, with, "Contribute to the needs of the saints; extend hospitality to strangers."

At the very beginning of the Church the Holy Spirit blended different ethics, customs, beliefs, historical background and created a new world without controversies. In the name of Christ, the Holy Spirit dissolved the fears and hesitation and created a bond between culturally opposed communities. The architect of the early Christian Church, Paul, tried with all his efforts and succeeded to built a universal Christian character without exclusions, capable to integrate all the differences. The religious transmission from another religion to Christianity was not easy, but it was guided by the Holy Spirit and the baptism. Furthermore it was so strong that could resist to any attack in the following centuries and integrate further cultures and beliefs.

\section{CONCLUSION}

Human beings, should find their realization (1) as persons only in relation to God, (2) in the end are measured more by their inner endowments than by their material or financial assets, and (3) are fundamentally relational creatures who need each other in community. Christian theology's principal task in the modern world is not to reject globalization but to humanize it, to make it more risk-averse to human costs than to financial costs, and above all to challenge people to become more interested in the human and spiritual assets of the global community than in the financial and material portfolio of its individual members.

${ }^{26}$ D. Christiansen, "Movement, Asylum, Borders: Christian Perspectives," International Migration Review 30:1 (1996) 7-17. 


\section{BIBLIOGRAPHY:}

[1] R. Byron, "Identity", Barnard, A. \& Spencer, J. (eds), Encyclopedia of Social and Cultural Anthropology, London: Routledge, 1996, p. 292. T. M. Luhrmann, "Identity in anthropology", Smelser, N. J. \& Baltes, P. B. (eds), International Encyclopedia of the Social \& Behavioral Sciences, Volume 21, Amsterdam: Elsevier 2001,

[2] J. G. Wenham, Genesis 1-15, [Word Biblical Commentary 1], Dallas, TX: Word Books 1987

[3] N. Blough, "From the Tower of Babel to the Peace of Jesus Christ: Christological, Ecclesiological and Missiological Foundations for Peacemaking", Mennonite Quarterly Review 76 (2002), 7-33.

[4] W. J. Aageson, "City-Building and the Benefits of Babel", Christian Century 106 (1989) 517-518. W. Brueggemann, Genesis. A Commentary for Teaching and Preachingi, Interpretation, Atlanta, GA: John Knox Press 1982, pp. 97-104. T. Hiebert, "The Tower of Babel and the Origin of the World's Cultures", Journal of Biblical Literature 126 (2007)

[5] F. O. Olojede, The Exodus and Identity Formation in View of the Origin and Migration Narratives of the Yoruba, University of Stellenbosch 2008

[6] C. Houtman, Exodus Vol. 2. Historical Commentaryon the Old Testament, Kampen: Kok 1996, p. 232.

[7] R. B. Dillard \& T. Longman, An Introduction to the Old Testament, Grand Rapids: Zondervan 1994, p. 66.

[8] M. Liverani, "Nationality and political identity", Freedman, D. N., (ed). Anchor Bible Dictionary, Volume 4. New York: Doubleday 1992, p. 1034.

[9] G. M. Brett, "Nationalism and the Hebrew Bible", Rogerson, J W, Davies, M \& Carroll, D. R. (ed.), The Bible in ethics: The second Sheffield colloquium, Sheffield: Sheffield Academic Press 1995, p. 151.

[10]Dietrich, W \& Klopfenstein, M. A. (eds.), Ein Gott allein? JHWH-Verehrung und biblischer Monotheismus im Kontext der israelitischen und altorientalischen Religionsgeschichte. Göttingen: Vandenhoeck \& Ruprecht 1994,

[11]D. G. Groody, "Building a Civilization of Love: Catholic Social Teaching and Immigration Reform," Sojourners, March 2010,

[12]D. L. Baker, Tight Fists or Open Hands? Wealth and Poverty in Old Testament Law, Grand Rapids, MI: Eerdmans 2009

[13]R. Carroll, Christians at the Border: Immigration, the Church, and the Bible. Grand Rapids, MI: Baker Academic 2008,

[14] W. R. O" Neill and W. C. Spohn, "Rights of Passage: The Ethics of Immigration and Refugee Policy," Theological Studies 59 (1998) 84-106.

[15]W. H. P. Lau, Identity and Ethics in the Book of Ruth: A Social Identity Approach, Berlin, Germany: De Gruyter 2011.

[16]L. Chan, "The Hebrew Bible and the Discourse on Migration: A Reflection on the Virtue of Hospitality in the Book of Ruth, Asian Horizons 8/4 (2014)

[17]D. Bergant, "Ruth: The Migrant Who Saved the People," G. Campese and P. Ciallella (eds.), Migration, Religious Experience, and Globalization, Staten Island, NY: Center for Migration Studies 2003 ,

[18]D. Christiansen, "Movement, Asylum, Borders: Christian Perspectives," International Migration Review 30:1 (1996) 7-17. 